\title{
THE RIGHT TO INCLUSIVE EDUCATION FOR CHILDREN WITH DISABILITIES IN THE REPUBLIC OF NORTH MACEDONIA: OPPORTUNITIES AND CHALLENGES
}

\author{
GORDANA STANKOVSKA ${ }^{1} \&$ IMRAN MEMEDI $^{2}$ \\ ${ }^{1}$ University of Tetova, Faculty of Philosophy, Institute of Psychology, Ilinden nn, Tetovo, Republic of \\ North Macedonia. ORCID: 0000-0002-1280-3412, Email: gorstankovska@gmail.com \\ ${ }^{2}$ University of Tetova, Faculty of Medical Sciences, Ilinden nn, Tetovo, Republic of North Macedonia. \\ ORCID: 0000-0002-4175-5616, Email: dr.imran.memedi@gmail.com
}

ABSTRACT: A child is a member of a vulnerable group in societies. Children's rights are equal for all children and they cannot be denied, because they are a birthright. However, throughout the world, children with disabilities and their families constantly experience a barrier in regard to the enjoyment of their basic human rights and to their inclusion in society. The situation began to change only when requirements to include disabled children in the education system were introduced in legislation. Following the example of other countries worldwide, the Republic of North Macedonia introduced inclusion of children with disabilities in the mainstream educational process. Hence, the main aim of our paper is to represent the actual situation in Macedonian schools regarding the problem of educational inclusion of students with disabilities in the regular school system. The research methods are based on document studies and case studies about changes in social and educational policies for students with disabilities and special educational needs who are included in primary and secondary education. At the same time we shall present some guidelines for teachers who work with these children and future directions for a proper inclusion system in the Republic of North Macedonia, because every child has a fundamental right to education and must be given the opportunity to achieve and reach an acceptable level of learning. In this frame, school societies try to support full participation of students with disabilities in areas of their lives on equal terms, conditions, social justice and 
basic human rights.

KEYWORDS: disabled children, special educational needs, human right, inclusion, challenges

\section{INTRODUCTION}

"Inclusion and participation are essential to human dignity and to the enjoyment and exercise of human rights."

(Salamanka Framework for Action, 1994)

Human rights are rights or powers that belong to each person, they are universal moral rights that are to be distributed among all human beings. Every human has their rights, according to the Universal Declaration of Human Rights (UN 1948), and children need special and increased protection, care, safety, understanding and love in order to develop in a healthy way. Children have special rights, because of their vulnerability, such as the right to protection from exploitation and abuse, the right to be carried for and have a home, and the right to have a say in decisions which affect them.

In this regard, historically many children with disabilities were not visible. They lived in large institutions, away from their families and communities. Now, most children with disabilities live at home, with their families, in communities across the country. However, this change has not resulted in children with disabilities becoming full and active members of the community. Throughout the world, children with disabilities and their families constantly experience a barrier in regard to the enjoyment of their basic human rights and to their inclusion in society (Raby 2008). Their abilities are overlooked, their capacities are overlooked, their capacities are underestimated and their needs are given low priority. The barriers they face are more frequently a result of the environment which they live rather than a result of their impairment. At the same time, the needs of parents who care for children with disabilities have also been excluded. Children with disabilities and their parents are not fully included in all aspects of the society and do not enjoy full citizenship (Valentine 2001). It means that children and families are able to participate with choice. It means that individual children are involved in activities and social structures in a way that is meaningful to their own experience. Real inclusion starts from the experiences of the child and challenges the society to provide a meaningful place for these children (Freiler 2002; Nussbaum 2007).

\section{THE MEANING OF THE TERM DISABILITY}

Children with disabilities are not a homogenous group. They may identify themselves more expressly with other aspects of their overall identify such as their gender, economic status, ethnicity or a combination. The belonging to one or several of these groupings significantly increases their vulnerability and dedication to addressing the 
right to educational needs in order to consider such multiple vulnerabilities (Singhal 2004; Nessner 1990).

A disability, of course, can be understood very differently, across different communities and cultures. Article 1 of the CPRD (The Convention on the Rights of Persons with Disabilities) describes these persons as "those who have long-term physical, mental, intellectual, or sensory impairments, which in interaction with various barriers may hinder their full and effective participation in society on an equal basis with others" (United Nations Committee on the Rights of Person with Disabilities 2016). This approach is consistent with the World Health Organization's (WHO's) International Classification of Functioning, Disability and Health, known more commonly as ICF, which conceptualizes a person's level of functioning as a dynamic interaction between her or his health conditions, environmental and personal factors (International classification of functioning, disability and health:ICF 2001).

As stated by Loreman and Deppeler (2001:16) "Inclusion means full inclusion of children with diverse abilities in all aspects of life and schooling that other children are able to access and enjoy. It involves regular schools and classrooms genuinely adapting and changing to meet the needs of all children, as well as celebrating and valuing differences.”

The enjoyment of human rights by children with disabilities can be fully realized only in an inclusive society, that is, a society in which there are no barriers to a child's full participation, and in which all children's abilities, skills and potentials are given full expression. Ensuring that children with disabilities receive good quality education in an inclusive environment should be a priority of all countries. The United Nations Convention on the Rights of Persons with Disabilities recognizes the right of all children with disabilities both to be included in the general education system and to receive the individual support they require (Convention on the Rights of Persons with Disabilities 2006).

Disability affects physical health, social relationships of people, life in the context of family, friends and neighbors or the level of independence. The consequences of a disability can have an impact at personal, interpersonal, family and social levels. In fact, a disability affects the different facets of life of a person and this life is often complicated by negative forces, such as ignorance, prejudice, negativism and insensitivity (Pijl, Frostad, and Flem 2008).

\section{CHILDREN WITH SPECIAL EDUCATIONAL NEEDS}

Special educational needs (SENs) refer to the special educational arrangements which are in place for people with disabilities (Citizens Information Board 2012). Griffin and Shelvin (2007) assert that any child may have special needs, and that not all special needs are related to education. Therefore, not all children with special needs will require special educational support.

Research and practice in special education show that children have special educational needs if they have a learning difficulty which calls for special provision to be made for them. Some children may have special educational needs for a relatively 
short time, they often have special educational needs directly through their education. So SENs means, in relation to a person, a restriction in the capacity of the person to participate in and benefit from education on account of an enduring physical, sensory, mental health or learning disability, or any other condition which results in a person learning differently from a person without that condition (Smith 2010).

Michailidis and Wilhelm (2009) indicate that the majority of children with special educational needs take part in mainstream education. The UK and other countries have based theirrecent policies on the assumption that up to one in five children may have a special educational need at some pointduring their education (Bines and Lei 2011:420). Stakes and Hornby (2000:8) identify eight different types of special educational needs, including: learning difficulties, visual difficulties, physical difficulties, developmental difficulties such as autism spectrum disorder or attention deficit hyperactivity disorder or intellectual disability, speech and language difficulties and emotional or behavioral difficulties.

Most children with SENs will have an appropriate provision made for them by their school while working with their parents. All professionals and parents realize that students with disabilities are human beings with a wide range of assets and limitations. There have, traditionally, been three broad approaches to the education of children with special educational needs: segregation, in which children are classified according to their impairment and allocated a school designed to respond to that particular impairment; integration, where children with disabilities are placed in the mainstream system, often in special classes, as long as they can accommodate its demands and fit in with its environment; and inclusion, wherethere is a recognized need to transform the culture, policies and practices in schools to accommodate the differing needs of individual students and an obligation to remove the barriers that impede those possibilities (Punch 2006). All children, including children with special educational needs, not only that they should have access to schooling within their own communities, but that should also be provided with appropriate learning opportunities to achieve their potential.

\section{INCLUSION AND INCLUSIVE EDUCATION: DEFINITION AND DISCOURSE}

Education for all (EFA) which represents an international commitment to ensure every child and adult receives basic education of good quality is focused on a human rights perspective and on the generally held belief that education is central to individual well-being and national development. So far, EFA has not paid sufficient attention to some marginalized groups of children, in particular those seen as having "special educational needs"or "disabilities" (Miles and Singel 2009).

In response to the perceived failures of EFA to date, a growing focus has been placed on inclusion as the key strategy for promoting the right to education, including the one for children with disabilities. Therefore, inclusion can be understood as a commitment to creating schools which respect and value diversity, and aim to promote democratic principles and a set of value and beliefs related to equality and social justice, so that all children can participate in teaching and learning (Minion 2011). Inclusion 
in education is not a marginal issue, rather it is central to the achievement of high quality education for all children and the development of more inclusive education (UNESCO 2005).

The term "inclusion" however, moves the focus from the child to the school - it conveys the school's duty to welcome pupils with special educational needs, and the pupil's right to full participation in school life and all aspects of education (Ainscow 2013). Cumming and Wong (2010:4) understand that inclusion implies"the rights of children with disabilities to access, participate and be equally included, alongside their peers in shared education and care settings, as well as having access to a broader community." They suggest that inclusion provides children with disabilities with more challenging learning settings and a chance to watch, learn and interact with more competitive peers. Also they found that the benefits of inclusion are most commonly identified in the domain of social competence, play and peer engagement.The key principles of inclusion refer to the following fundamental concepts:

- Valuing diversity;

- The right to be respected;

- The dignity of the human being;

- Individual needs understood as individual requests;

- Planning;

- Collective responsibility;

- Development of professional relations and culture;

- Professional development and equal opportunities.

Inclusive education represents a continuous process of improving the school, aimed at expropriating existing resources (especially human resources), as a perspective, and as it has been done to present day. This perspective is much closer to the ideal school of the future, which strives to offer services as a response to a variety of educational demands expressed by different children, without becoming an exclusivist environment (Barnett et al. 2003).

Inclusive education is a human right issue. Inclusive education means changes and adoption of a mainstream education system in the whole society in order to meet the special needs of children with disabilities.

Inclusive education primarily pertains to the practice of enabling children with a developmental problem to exercise their right to education along with all other children and to attend a neighborhood school that theywould normally attend if they did not have developmental problems. Literature suggests that students with special needs who have been educated in regular classes have better academic and social achievements than comparable students in non-inclusive settings (Gordon 2013).

Inclusive education should play a key role to ensure individual development and 
social inclusion, enabling children and youth with disabilities to attain the highest possible degree of autonomy and independence. Within this frame, school societies try to support full participation of children with disabilities in all areas of their lives on equal terms and conditions (Jha 2002).

\section{THE RIGHT OF CHILDREN WITH DISABILITIES TO INCLUSIVE EDUCATION IN THE REPUBLIC OF NORTH MACEDONIA}

The tendency in most European Union countries is to develop policies that promote inclusion as an important process in democratic societies, which gives equal opportunities to everyone and maximum flexibility in meeting the specific and social need of the individuals. Having in mind that inclusion is a developing and a dynamic process, the developmental level of inclusion in the member states varies. Same as many other southeast Balkan countries, the Republic of North Macedonia has been facing a challenge to steer the national policies towards creating societies that are structurally based on the principle of equal rights to all, according to which people have equal rights and opportunities, individual differences and respects and they lead towards building an inclusive society. The general intention of Macedonian institutions is to build an inclusive society in terms of abilities, ethnicity and socio - economic inclusion. According to the Constitution of the Republic of North Macedonia, all children have the right to education. In the Constitution, in terms of economic, social and cultural rights governing the right to education it is indicated that"Everyone has the right to education. Education is accessible to everyone under equal conditions"(Human Rights and Education Country Guide 2016). The education of children and adolescents with disabilities is an integral part of the unique educational system in our country. The state is committed to the inclusion of all people in all areas of life regardless of the type and degree of the disability. This tendency implies inclusion at all educational levels.

The actual conceptual placement of the education for students with special needs is regulated with the Law on Primary Education (2008) and the Law on Secondary Education (1995).

In addition in the relevant laws, in 2010 the Government has adopted the national strategy for standardization of the rights of persons with disabilities, which is based on a thorough comprehension and analysis of the need for the Government to adopt adequate decisions for protection, education, rehabilitation, training and employment of disabled persons (National Council of Disability Organizations of Macedonia 2011). The Strategy foresees realization of seven specific measures related to educational needs and requirements of children with disabilities:

- Development of programs for inclusion of children with special needs in the educational system, including pre-school education;

- Application and improvement of the existing legislative provisions that define the field of discrimination in the educational process at all levels of education;

- Individual work with the children by engaging special educators in regular 
schools in addition to special education schools;

- Guidance of the SEN pupils according to their needs and preferences;

- Development of motivational programs for the parents throughout the education of their children, which will contribute to raise awareness about the inclusive approach in the education;

- Provision of training for the teaching staff, school directors and professional associates in the school for support and implementation of the inclusive education.

The realization of these measures and activities is a responsibility of the Ministry of Education and Science and the Municipalities as the local educational authorities. The right to education for persons with disabilities is defined in Article 24 of the Convention on the Right of Persons with Disabilities which our country ratified in 2011.

\section{INCLUSIVE EDUCATION IN THE REPUBLIC OF NORTH MACEDONIA: PAST EXPERIENCE AND FUTURE POSSIBILITIES}

Today inclusive education is considered an aspect of the quality of the education system. For that reason, the European Union and UNESCO in most of their recommendations provided guidance to ensure that a sociopolitical issue is well-addressed. Although inclusive education is most commonly associated with children with developmental disabilities, it, in fact, concerns all socially marginalized groups of children (ethnic minorities, children from culturally deprived backgrounds, children of displaced persons and refugees, children from disadvantaged socio-economic conditions, etc.).

In order to adequately promote the idea of inclusive education, a great number of foreign humanitarian organizations (i.e. UNESCO, UNICEF, Save the Children UK...), in the last 20 years, in collaboration with the Ministry of Education and Science of Macedonia, have organized numerous educational and training programs for teachers, professionals and parents of children with disabilities with a main goal to find solutions and ways to satisfy the child's needs (Ministry of Education and Science 2002).

One early project in the field of inclusive education was the "Modernization of the Education of Persons with Disabilities"in the Republic of Macedonia which was carried out in the period from 1996 to 1998. The project resulted in some changes in the Law on Primary and Secondary Education. The norms and standards regulate the education of teachers with special educational needs (OECD 2006:152).

In the period from 2000 to 2005, the Ministry of Education and Science implemented a project titled "Inclusion of children with special needs in regular schools." In 2005 , five years after the project, there were 73 primary schools and 13 kindergartens where children with special needs were included. The project began by offering seminars for teachers and professionals (psychologists, pedagogues or special educators) from mainstream schools. As a result of this project, special methods and forms of work and inclusion in the educational process, as well as other forms of individual and 
group work have been proposed (OECD 2006:153).

UNICEF in collaboration with the Ministry of Education and Science also implemented several pilot projects for inclusive education in preschool institutions from 2010/11 to 2016/17 and from 2011/12 to 2017/18 in several elementary schools in the Republic of Macedonia (UNICEF 2017). During these pilot projects two priorities were identified in order to achievea significant change towards inclusive education for children with special needs: (a) to change teacher's attitudes; (b) to change attitudes of parents and the community by increasing their involvement and support.

It is true that inclusion cannottake placewithout a systematic approach. Even in ideal circumstances, when the school is a "friendly" environment for a child with special educational needs, interventions from the system, networking and link are still needed. Hence,the reformed schools in the Republic of North Macedonia open the door for inclusion of children with special needs in regular education. The Macedonian education system aims to include all children with special needs in regular schools or kindergarten groups. Hence, inclusive education is introducedin certain elementary schoolsthroughout the country. There is an observable progression of the number of students with special educational needs that attend inclusive schools in the regular educational system. The number has increased from 471 students in 2014/15 to 1451 students in 2017/18 (Ministry of Education and Science, Bureau of Education Development 2018:64).

In kindergartens, teachers are the primary helpers of the children; professional counselors with appropriate training may also assist when available. Teachers engage in regular activities with the children, trying to respect the principle of an individual approach, so that children with developmental difficulties are offered activities appropriate for their capacities. Individual work is carried out on the basis of the individual program which is constantly monitored in terms of the need to introduce changes. Children with developmental difficulties need to play and socialize with other children. By means of play, pre-school settings can help children learn about themselves and about the others (Ruijs and Thea 2009).

In elementary schools, from grade 1 to grade 6 , teachers also work directly with the children and later the children are expected to continue their education in regular further grades, on the basis of their level of achievement, with or without individual programs and further assistance. Of course, teachers do not receive pre-established individual programs for work with particular children and must create such programs by themselves, in order to define target attainments for the child. The process is based on experience and intuition. Furthermore, school pedagogues, psychologists and speech therapists advise and educate students and parents, and assist teachers with instructions or provide some assistance in classes. Other difficulties arise in the transition from class to subject teaching after the sixth grade. Class teachers may be more tolerant towards children with special needs while in subject teaching, each teacher will spend less time with a specific student and therefore, will be less able to follow through with additional assistance (Ainscow 2005). Sometimes school experts can provide support, but many have not been trained in this field yet.

Secondary education as well as primary education are mandatory. According to 
Article 39, paragraph 1 of the Law onAdultEducation, in secondary schools students with special educational needs are educated according to adequate curriculums for students with special needs, but also with programs for the appropriate vacations in vocational training (Law on Adult Education 2015:16). One important opportunityto increase training of academic staff can be notices in the new Law on Primary and Secondary Education, which obliges educators to attend in service training on a regular basis, providing an excellent occasion to include new approaches in the primary and secondary education system. Increased training would later enable teachers to accomplish inclusive education in the future.

In addition, inclusion unavoidably was an integral part of the development of the Education Strategy 2018-2025 in the context of lifelong learning and the Action Plan, which had be adopted by the Ministry of Education and Science and the Government of the Republic of North Macedonia (Ministry of Education and Science 2018). At the same time, according to the Macedonian education system it was planned for the students with special educational needs to be included in mainstream school, while the new special schools should be built in the vicinity of regular schools, in order to ensure contact and interaction and promote inclusion where possible.

None of these difficulties is insurmountable, however, if considered together, they present a series of big challenges to be met in the development of inclusive education in the Republic of North Macedonia.

\section{RESEARCH METHODOLOGY}

This study is a part of project called "Inclusive education and support of children with developmental disabilities" implemented by the expert team of the Association of Citizens for Psychological, Defectology and Speech Therapy "Center Savant" Skopje with the support of the Municipality of the "City of Skopje." The main goal of this study was to explore the reality of inclusive education of students with disabilitiesin mainstream secondary schools in Skopje, from the perspectives of secondary school teachers, students without disabilities and parents of children with disabilities. As an outcome of the completed project activities in 2019, significant effects were concluded which created the base for exploration of possibilities to extend the network with new project schools. To that end, in order to determine the attitudes, knowledge and experience of teachers, peers and parents, in the first four project schools in regard to the inclusive practice, a research was carried out in the period from September to December, 2019. A total number of 246 respondents were included in the research, of which: 40 parents, 89 teachers and professionals from secondary schools and 117 students from the first to fourth year of secondary education within the same schools.

For the purpose of this study, a qualitative research design was chosen. In fact, a qualitative approach was adopted since it provides the best support aimedat gaining greater understanding of inclusive education, from the perspectives and experiences of those involved, namely teachers, peers and parents of children with disabilities. A combination of sampling techniques was used for this study. Convenience sampling was used as the researchers selected four local schools together with the represen- 
tative from the Department for Education from the City of Skopje. Purposive technique was also employed since the researchers wanted to gain insights from teachers who were in mainstream secondary schools and had experience in working with children with special needs within their mainstream class groups. The study also required insights from parents who had a child with special educational needs and who was attending a mainstream school setting. The third group were the students without disabilities who learned together with their peers who had some kind of developmental difficulties (e.g. autistic spectrum disorder, Down syndrome, learning difficulties, cerebral palsy).

In order to invite candidates to take part in the study, contact was established initially with the principle or the vice principal of the school. By using a network sampling technique, they were asked to convey the information and the invitation to participate tothe members of the teaching staff, peers and parents of students with special educational needs attending the school. The parents were contacted by the school principals and teachers. Confidentiality and anonymity of children, family and school was reiterated to all participants at this point. The contact with participants was held at the school premises during school hours. At the same time, we respect the participant's right to anonymity, confidentiality and privacy, and give participants clear information about the study. The researchers communicated openly and honesty with all participants in this study. All information - written and recorded - was stored securely, whereby access was available only to the researchers. Contact details for the researchers were also included, for any further questions.

The research included three modules of work.

\section{Module 1. Workshops with students without disabilities}

The main purpose of these workshops was to educate students on accepting and supporting their peers with some form of disabilities, but at the same time to teach them how to reduce their prejudice towards their peers. During the workshops, different forms of activities involving the students were organized: role plays, discussions, films and competitions. For example, students from 16 to 18 years of age, from secondary school, spent 5 days undertaking photography activities with a camera. Students with disabilities were paired with their non-disabled peers. Together they shared the photos and discussed. This type of activity provided them the opportunity to learn or develop their skills, but above all, it contributed to breaking down barriers between children with and without disabilities. The results demonstrated how positive attitudes and friendships can grow within a short time by using a very simple, but a powerful tool - a camera. The research has very effectively promoted a message that all children can and must be educated together.

\section{Module 2. Work with parents}

The work with parents wasfocused on training, support, knowledge, communication skills and legal advice. After this activity,the parents acquire a positive experience of 
the abilities of their child and develop a partnership which provides support and encouragement to parents in their effort to do as much as possible for their children. We found that the parents were very satisfied with their children's experience of mainstream education, for example:

We always considered the other children as well.....so we had to learn how to adjust over the years and think about what was best, not just what we wanted for her, but what was best for everybody. I really wanted my girl to go to a mainstream school. I think we all have the idea of the school we would like our kids to attend.

(Parent of an autistic child)

Also the participants identified social learning and social awareness as positive aspects of inclusive education settings. It is not only children with disabilities who have a social benefit, this applies forall children at school.

Since he started school he has been spending more time with his peers than with his family. So they are his educators; they are his everything; they are his world, and he is not the onlychild with a disability in the school, so he himself would be helping them.

(Parent of a child with cerebral palsy)

Regarding the inclusive processes, the views of the parents are divided, depending on their personal experiences, the degree of disability their child has and whether the society has accepted their child or not. Still, some parents are not satisfied with the inclusive education and they believe that there is not any real inclusion in the country and that it all depends on the parents and their means.

\section{Module 3. Training and support for teachers}

No single change in the educational process can take part into practice without the teacher, because the teacher is and remains to be the key factor in the implementation of the educational process. Teachers are the ones who can understand every change. According to this, the researchers organize trainings for teachers, psychologists and officials about inclusive education issues. Participants were invited to share their views and experiences on various themes related to inclusion in education. During these activities teachers same as the parents, should share the same view of what the term inclusive means, they express positive attitudes concerning the acceptance of children with special educational needs in regular school by their schoolmates and positive attitudes concerning the need of additional assistance by a special needs assistant as a specialized person within the framework of inclusive practice. Also the largest number of teachers were determined to design an individual educational program (IEP) as one of the forms for additional necessary assistance. From the discussion on children's social interaction, an emphasis on the caring nature exhibited by secondary school students towards pupils with special educational needs became evident.

He would be verywell looked after in the class and they would include him as much as possible...But for him, you know, whether he would considerany of them as his 'real' 
friends, Ido not know if he would. But yet he really enjoys being with them...

\section{(Teacher of a student with Down syndrome)}

Although teacher training courses have more recently incorporated modules on inclusion in education and students can avail of placement practice inspecial needs settings, we found that teachers feel it is not enough to prepare them for the needs of all children attending mainstream education. The results indicated that $60 \%$ of the teachers from the secondary schools had no training or experience in working with students with special educational needs, but $90 \%$ of them believed that every teacher would receive training in order to work better with these children.

Teachers need confirming education (training, access to literature, workshops, instruments). This helps them overcome negative, individual medical model-based perceptions and attitudes. Thus, they need to acquire skills for supporting students and establishing collaboration with parents. In this regard, training content related to human rights, the social model of inclusion, defining inclusive education, the twin track approach, learning styles and individual planning really help (Kane et al. 2003). The school inclusion team uses this training content adapted to our context.

The participation in this inclusive education project encouraged us to reconsider school challenges in our country. Our participation in the last training module was a new stimulus to focus on the current inclusive processes and the school's future potential. According to this, we should share this case study as good a practice for creating conditions that enable students with disabilities to enroll and successfully progress in an inclusive school.

\section{CASE STUDY: A 16-YEAR-OLD GIRL WITH DOWN SYNDROME}

The student Lilly had intellectual impairments. The girl had developed during her first year of life, but problems emerged (when she was at the age of 17 months). The parents noticed an attention deficit, she did not respond to her name and had speech difficulties. During her early childhood, the girl received speech therapy three times a week and worked individually with a special educator. Her parents followed her progress, because at the age of 7 the little girl could count to 10, she knew relations, colors, shapes and letters. The speech therapist and the special educator together decided that she had abilities, needs and potentials to be in educational settings together with her peers in a local mainstream primary school. Here her teachers helped and encouraged her to play with other children. An education inclusion team together with teacher and parents made an individual educational plan (IEP). An IEP was developed, which specified learning goals for Lilly that matched her abilities and identified needs. The following instructional methods/strategies have been used with Lilly:

- Individualized approach;

- Working in pairs and a small group;

- Play, observation, showing images, applications, objects, toys, illustrative 
method, dialogue, practical work;

- Development of individual instructional booklets for educational purpose;

- Use of teaching aids, educational software, practical didactical tools.

Apart from having a good achievement level according to her abilities and the educational goals set out in IEP, Lilly was included in all activities of the school community (school performances, exhibitions, after-school activities, etc.).

Now Lilly is in first grade of secondary school and she still needs support, because the new environment and greater mobility in the classroom still upset her, but her new teachers helped and encouraged her to feel better between her new peers. In fact the teachers were a part of Module 3 and they explained us their plan of Lilly's future education. The new action plan of the school inclusion team would be made for her. This includes organizing meetings to exchange views and experiences among teachers who teach those students, providing individual support, understanding her socioemotional status, because she is in period of adolescence and taking action for improvement, etc. The monitoring of the implementation of the IEPs shows that she is mostly achieving her goals, although if her parents were more fully engaged in the process, the results could be even better. Lilly has an opportunity to finalize the requirements of inclusive education. She hopes to go to college and study art.

Up until now, her inclusion in mainstream school has been extremely positive. Lilly is happy. Her parents are happy. The school team is happy.

\section{CONCLUSION AND RECOMMENDATION}

Inclusive education as the single special route leads to an inclusive society. All children at some point need special attention and support, so that they can more easily overcome daily challenges, or perhaps specific storms they are facing and going through.

Every child is special, talented and prone to success in some field. Every child needs to play, learn and socialize with the children. Every child has a right to participate in a regular kindergarten or school according to their pace (Freeman 2000; Subramanian 2003). This is especially important to children with disabilities, because school settings can help them learn more about themselves, the others and the world. The world is a big place with lots of opportunities!

Every child has a fundamental right to education and must be given the opportunity to achieve an acceptable level of training (De Valenzueala et al. 2006). Every child has unique characteristics, interests, abilities and learning needs, so an educational system should be designed and an educational program should be implemented in order to take into account the wide diversity of these characteristics and needs.

On the basis of our findings and lessons learned from all of the training modules on inclusive education, and the inclusion story of Lilly, we would give the following recommendations:

- To accept inclusion as an obligation; 
- To enable higher level of participation of students with developmental disabilities in creating educational programs, as well as during the enrolment in the first grade of secondary school;

- To implement active teaching strategies by teachers as the base for the inclusive approach;

- To create a warm environment with complete respect for everyone, so that all children are equally valuated and encouraged;

- To involve children with special educational needs in all varieties of activities, depending on the abilities the child has;

- To balance the rights of children with special needs and interests, with the goals and interests of their parents;

- To achieve better social integration and socialization by supporting development of the sense of security, satisfaction and self-esteem;

- The need to invest in the development of measures and services for increasing the quality level of involvement of children with developmental disabilities in the community.

Finally, continuous inclusive process across the whole school, through connecting and networking activities based on the principle: "you can teach and you can learn".

FUNDING: This research received no external funding.

CONFLICT OF INTEREST: The authors declare no conflict of interest.

ACKNOWLEDGEMENTS: We would liketo express their gratitude to all teachers, parents and children without disabilities who participated in this study.

\section{REFERENCES}

Mel, Ainscow. 2013. "Making sense of inclusive education." Trinity Education Papers: Examing theory and practice in inclusive education 2(2): 2-11.

Mel, Ainscow. 2005. "Developing inclusive education systems: what are the levels for change?” Journal of Educational Change 6: 109-124.

Barnett, Douglas, Melissa Clements, Melissa Kaplan-Estrin, and Janice Fialka. 2003. "Building new dreams: Supporting parents'adapdation to their child with special needs.” Infants and Young Children 16(3): 184-200.

Bines, Hazel and PhilippaLei. 2011. "Disability and education: The longest road to inclusion." International Journal of Educational Development 31: 419-424. DOI: 10.1016/j.ijedudev.2011.04.009. 
Canadian Association for Community Living (CACL). 2002. Translating needs into policy directions: A community paper. Winter.

Citizen's Information Board. 2012. Special needs education: Tha law on special needs education. Retrieved from (http://www.citizensinformation.ie/en/education/ the_irish_education_system/special_education.html).

Convention on the Rights of the persons with Disabilities. 2006. New York: United Nations. Retrieved from (https://www.un.org?disabilities/default.asp?id=150).

Cumming, Tamara and Sandie Wong. 2010."Family day care is for normal kidsd: facilitators and barriers to the inclusion of children with disabilities in family day care." Australian Journal of Early Childhood 35(3): 4-12.

De Valenzuela, Joseph S., Susan R. Copeland, Cathy Q. Huaqing, and MinhaPark. 2006. "Examining educational equity: Revisiting the disproportionate representation of minority students in special education." Exceptional Children 72(4): 425-41. https://doi:org/10.1177/001440290607200403.

Freiler, Christa. 2002. Understanding social inclusion. Toronto: The Laidlaw Foundation.

Freeman, Michael. 2000. "The future of children's rights." Children and Society 14: 277293. https://doi.org/10.1111.jo1099-0860.2000.tb00183.x.

Gordon, John S. 2013. "Is inclusive education a human right." Journal of Law, Medicine and Ethuics 34: 754-765. https://doi.org/10.1111/jlme.12087.

Griffin, Sean and Michael Shelvin. 2007. Responding in special needs education: An Itish perspective. Dublin: Gill and Macmillian.

Human Rights and Education Country Guide. 2016. Skopje. Retrieved April, 2018 (http://globalnaps.org/files/8401_guidebook).

International classification of functioning, disability and health: ICF. 2001. World Health Organization: Geneva.

Jha, Mohan M. 2002. Scholl without walls: Inclusive education for all. Oxford: Heinemann.

Law for primary education. 2008. Official Gazette of Republic of Macedonia. No. 103/08 from Setember 8, 2008. Retrieved from (https://www.legislationline.org. document)

Law for secondary education. 1995. Official Gazette of Republic of Macedonia. No. 44/95 from September 9, 1995. Retrieved from (https://www.coe.int.org.document).

Law for adult education. 2015.Official Gazette of Republic of Macedonia. No. 146/2015 from January 15, 2015. Retrived from (https://www.pso.mon.gov.mk/wp-content).

Loreman, Tomas and John M. Deppeler. 2001. "Inclusive education in Victoria.” Interaction 14:13-17.

Kane, Jean, Sheilla Ridell, Peter Banks, Anna Baynes, and Alison Wilson. 2003. “Special educational meeds and individualised educational programmes: issues of parent and pupil participation." Scottish Educational Review 36(1): 38-48.

Michailidis, Panagits D. and Wilhelm Reich. 2009. "Dilemmas of inclusive education." European Journal of Disability 3: 24-44. DOI: 10.100/08856250903450830. 
Miles, Susie and Nidhl Singel. 2009. "The education for all and inclusive education debats: conflict, contradiction or opportunity." International Journal of Inclusive Education 11(1): 1-15. https://doi.org/10.1080/1360311080226125.

Ministry of Education and Science. 2002. Educational Developmental Strategy 20012010. Skopje.

Ministry of Education and Science, Bureu of Education Development. 2018. Actual situation with inclusion of children with special educational needs in education system in Republic of North Macedonia. Skopje: Ministry of Education and Science of the Republic of Macedonia.

Ministry of Education and Science. 2018. Education strategy for 2018-2025 and Action Plan. Skopje: Ministry of Education and Science of the Republic of Macedonia.

Minion, Tomas. 2011. "New trends in education of children with disabilities." Procedia - Social and Behavioral Sciences 15: 1955-1959.

National Council of Disability Organizations of Macedonia. 2011. Findings and conclusion of the held roundtable for education. Skopje.

Nessner, Katherine. 1990. "Children with disabilities."Canadian Social Trends 19: 1824.

Nussbaum, Martha. 2007. “Education for world citizenship needs to begin early.” Early Childhood Matters 1(5): 15-19.

OECD. 2006. Fyr of Macedonia, in Education policies for students at risk and those with disabilities in South Eastern Europe. OECD Publishing: Paris.

Pijl, Sip J., Per Frostad, and Annlaug Flem. 2008. “The social position of pupils with special needs in regular schools.” Scandinavian Journal of Educational Research 52(8): 387-405. https://doi.org/10.1080/00313830802184558.

Punch, Keith. 2006. Developing effective research proposals. London: Sage.

Raby, Rebecca. 2008. “Frustrated, resigned, outspoken: Student's engagement with special rules and some implications for participary citizenship.” The International Journal of Children's Rights 16(1): 77-98. DOI: 10.1163/092755608x267148.

Ruijs, Nienke M. and Thea D. Peersma. 2009. "Effects of inclusion on students with and without special educational needs reviewed." Educational Research Review 4: 67-79.

Singhal, Nidhi. 2004. Education in $21^{\text {st }}$ Century, Conflict, Reconciliation and Restruction. Paper presented at the Brirish association for International and Comparative Education (BAICE) Conference. University of Sussex, September 3-5, 2004.

Singhal, Nidhi. 2015."Inclusive education in an Indian context ."Educational Research Review(6)4:134-179. https://doi.org/10.1080/10349120600847797.

Smith, Philip. 2010. Whatever happened to inclusion: The place of students with special educational needs. New York: Peter Lang.

Stakes, Richard and Gurry Hornby. 2000. Meeting special needs in mainstream schools. London: David Fulton Publishers.

Subramanian, Richard. 2003. "Right to education opportunities and challenges.” Education Dialogue 1(1): 76-95.

UN. 1948. Declaration of human rights. New York. Retrieved February 3, 2017 (http:// narodne-novine.nn.hr/clanci/megunarodni/2009_11_12_143.html). 
United Nations Committee on the Rights of Person with Disabilities. 2016. Right ro inclusive education. General Comment No 4: Aricle 24. Retrieved from (http://www. right-to-education.org/resource/2016).

UNICEF. 2017. The right of children with disabilities to education. Geneva: National Council for Special Education.

UNESCO. 1994. The Salamanka Statement and Framework for Action on Special Needs Education. Paris: UNESCO.

UNESCO. 2005. Guidelines for inclusion ensuring access to education for all. Paris: UNESCO.

Valentine, Fraser. 2001. Enabling citizenship: Full inclusion of children with disabilkities and their parents. Ottawa: Canadian Policy Research Networks.

\section{BIOGRAPHICAL NOTE}

Gordana Stankovska is professor of clinical psychology at the Institute of Psychology and Psychiatry at the Faculty of Medical Sciences, Republicof North Macedonia.

Memedi Imran is PhD Candidate of psychiatry at the Faculty of Medical Sciences, Republicof North Macedonia.

OPEN ACCESS: This article is distributed under the terms of the Creative Commons Attribution Non-commercial License (CC BY-NC 4.0) which permits any non-commercial use, and reproduction in any medium, provided the original author(s) and source are credited.

ARTICLE HISTORY: Received 2020-03-12 / Accepted 2020-07-04 
